\title{
LEMBAR KERJA PESERTA DIDIK BERBASIS INKUIRI TERBIMBING DENGAN MEDIA MANIPULATIF DALAM PEMBELAJARAN MATEMATIKA
}

\author{
Yulia Leha.Mc ${ }^{1}$, Retno Marsitin ${ }^{2}$, Trija Fayeldi ${ }^{3}$ \\ Program Studi Pendidikan Matematika, Universitas Kanjuruhan Malang ${ }^{1,2,3}$ \\ yulialeha22@gmail.com ${ }^{1}$ \\ mars_retno@unikama.ac.id ${ }^{2}$ \\ trija_fayeldi@unikama.ac.id
}

\begin{abstract}
Abstrak. Salah satu bahan ajar yang digunakan sebagai panduan dalam melakukan kegiatan penyelidikan atau pemecahan masalah yaitu Lembar Kerja Peserta Didik (LKPD). Penelitian ini bertujuan untuk mengembangkan bahan ajar berupa LKPD berbasis inkuiri terbimbing berbantuan media manipulatif pada materi bangun datar dalam pembelajaran matematika di SMP Negeri 5 Mukok Kalimantan Barat. Metode yang digunakan adalah Research and Development (R\&D) dengan model ADDIE yang meliputi: Analysis, Design, Development, Implementation, dan Evaluation. Teknik pengumpulan data yaitu wawancara dan angket. LKPD divalidasi oleh ahli materi, ahli media, dan ahli pembelajaran. Uji coba dilakukan pada kelompok kecil 9 peserta didik kelas VIIB dan kelompok besar 20 peserta didik kelas VIIA. Hasil validasi ahli materi, ahli media dan ahli pembelajaran dinyatakan valid. Hasil angket respon uji coba kelompok kecil dan kelompok besar masing-masing diperoleh skor 3,64 dan 3,68 dengan kriteria sangat layak. Keefektifan LKPD masing-masing diperoleh persentase ketuntasan sebesar 78\% dengan kriteria baik dan $90 \%$ dengan kriteria sangat baik. Hasil tes diperoleh total persentase ketuntasan sebesar $84 \%$ dengan kategori sangat baik. Sehingga, disimpulkan LKPD ini valid, layak dan efektif diterapkan pada materi bangun datar. Saran untuk peneliti selanjutnya agar dapat mengimplementasikan LKPD dengan bantuan berbagai media pembelajaran matematika.
\end{abstract}

Kata Kunci: LKPD; inkuiri terbimbing; media manipulatif 


\section{PENDAHULUAN}

Proses belajar yang dilalui oleh peserta didik tidak sekedar membaca, mengingat, dan mengerjakan soal-soal latihan, melainkan juga melalui proses mengalami. Menurut Bruner (Ningsih, 2014) belajar matematika adalah belajar mengenai konsep dan struktur matematika yang terdapat dalam materi yang dipelajari serta mencari hubungan antara konsep dan struktur matematika. Banyak peserta didik yang beranggapan bahwa matematika merupakan mata pelajaran yang membosankan untuk dipelajari. Oleh karena itu, pembelajaran matematika perlu diperbaharui dengan cara penggunaan model pembelajaran yang memberikan keterlibatan peserta didik secara aktif (Purwasih, 2015). Salah satu hal yang perlu diperbaharui oleh pendidik dalam pembelajaran matematika adalah model pembelajaran dengan menggunakan Lembar Kerja Peserta Didik (LKPD) yang sesuai dengan Kurikulum 2013 Revisi 2017 yang telah ditetapkan oleh pemerintah.

Berdasarkan observasi dan wawancara dengan guru pengajar di SMP Negeri 5 Mukok Kalimantan Barat, proses belajar mengajar masih menggunakan metode ceramah, tanya jawab dan pemberian soal tugas yang di ambil dari buku-buku pemerintah dan soal yang dibuat oleh pendidik. Hal ini menyebabkan peserta didik tidak aktif dalam proses pembelajaran serta hasil belajar peserta didik yang memenuhi KKM tidak mencapai $60 \%$. Proses pembelajaran ini dapat menjadi aktif jika berpusat pada peserta didik sesuai dengan Kurikulum 2013 revisi 2017.

Penggunaan LKPD di kelas bertujuan untuk memudahkan peserta didik dalam melaksanakan proses belajar (Indraningtias \& Wijaya, 2017). LKPD ini dapat disesuaikan dengan model pembelajaran yang digunakan dalam Kurikulum 2013 dengan menggunakan pendekatan saintifik. Salah satu model pembelajaran yang digunakan dalam pendekatan saintifik adalah inkuiri. Inkuiri terbimbing yaitu inkuiri yang dalam pelaksanaannya pendidik menyediakan bimbingan dan petunjuk kepada peserta didik dalam pemecahan masalah (Damayanti, 2013). Pada inkuiri terbimbing ini, pendidik membuat petunjuk percobaan dan peserta didik melakukan percobaan untuk menemukan konsep-konsep yang telah ditetapkan oleh pendidik. LKPD berbasis inkuiri terbimbing ini dapat dibantu dengan media pembelajaran.

Penggunaan media pembelajaran dapat menarik perhatian dan minat peserta didik dalam kegiatan pembelajaran serta memberikan pengalaman lebih nyata. Salah satunya adalah penggunaan media manipulatif dalam LKPD inkuiri terbimbing dapat membantu peserta didik dalam memahami dan menemukan konsep-konsep mengenai materi yang diajarkan oleh pendidik. Media manipulatif ini berupa benda yang dapat dilihat, disentuh, didengar, dirasakan, dan dimanipulasi (Riana, 2013).

Penelitian sebelumnya (Indriani, 2017) sebagai penunjang tentang Pengembangan Lembar Kerja Peserta Didik (LKPD) Berbasis Inkuiri Terbimbing Pada Materi Transformasi Geometri dengan tahap prosedur penelitian Preliminary dan Formative Evaluation, yang menyimpulkan bahwa LKPD dinyatakan valid, praktis, dan efektif. Penelitian pada artikel ini berbeda dengan penelitian sebelumnya. Pada artikel ini penelitian menggunakan model pengembangan ADDIE serta uji coba LKPD pada peserta didik dilakukan dengan bantuan media manipulatif yang terbuat dari kertas berwarna pada materi bangun datar.

Penelitian dilakukan untuk menguji kelayakan dan keefektifan serta mengetahui respon peserta didik terhadap LKPD Berbasis Inkuiri Terbimbing Berbantuan Media Manipulatif pada Materi Bangun Datar Segi Empat. Penelitian penting dilakukan, karena banyak peserta didik yang tidak aktif dalam kegiatan pembelajaran. Hasil dari penelitian pada artikel ini diharapkan dapat menjadi masukkan bagi pendidik dalam kegiatan pembelajaran.

\section{METODE PENELITIAN}

Penelitian ini menggunakan penelitian dan pengembangan (Research and Development). Menurut Sugiyono (Fannie \& Rohati, 2014) penelitian dan pengembangan adalah metode penelitian yang digunakan untuk menghasilkan produk tertentu, dan menguji keefektifan produk tersebut. Menurut Arikunto (Iskandar, 2018) metode penelitian merupakan cara yang digunakan oleh peneliti dalam mengumpulkan data penelitian. Penelitian ini mengacu pada model ADDIE yang meliputi : Analisis (Analysis), Perencanaan (Design), Pengembangan (Development), Implementasi (Implementation), dan Evaluasi (Evaluation). 
Langkah pertama yaitu dilakukan analisis untuk mengetahui kebutuhan awal dalam mengembangkan LKPD ini. Tahap pertama yaitu analisis kurikulum yang dilakukan dengan cara memilih materi matematika yang akan menjadi pokok bahasan pada media ini, serta menganalisis Kompetensi Inti, Kompetensi Dasar, dan Indikator yang harus dicapai peserta didik setelah mempelajari pokok bahasan tersebut. Tahap yang kedua yaitu analisis karakteristik peserta didik yang dilakukan untuk mengetahui karakteristik peserta didik kelas VII SMP Negeri 5 Mukok Kalimantan Barat. Analisis ini dilakukan dengan cara observasi dan menanyakan kepada guru mata pelajaran. Dari analisis tersebut akan diketahui perkembangan berpikir yang telah dicapai peserta didik kelas VII SMP Negeri 5 Mukok Kalimantan Barat, sehingga dalam pengembangan LKPD berbasis media manipulatif ini dapat disesuaikan dengan kemampuan dan tingkat berpikir peserta didik. Tahap terakhir yaitu analisis pemanfaatan LKPD berbantuan media pembelajaran. Analisis ini bertujuan untuk mengetahui sejauh mana pemanfaatan LKPD berbantuan media pembelajaran yang digunakan pada saat pembelajaran matematika dan bagaimana LKPD yang dibuat dapat memenuhi kebutuhan peserta didik.

Langkah kedua yaitu perencanaan, dimana peneliti membuat desain produk yang akan dikembangkan. Peneliti menentukan unsur-unsur yang akan dimuat dalam LKPD berbasis inkuiri terbimbing berbantuan media manipulaif serta alur pembelajaran. Desain ini nantinya akan dikonsultasikan pada dosen pembimbing. Revisi akan dilakukan jika desain tersebut belum sesuai. Jika desain telah dinilai baik, proses pengembangan akan meningkat pada tahap selanjutnya yaitu pembuatan LKPD Berbasis Inkuiri Terbimbing Berbantuan Media Manipulatif pada materi bangun datar. Langkah ketiga yaitu pengembangan LKPD berbasis inkuiri terbimbing berbantuan media manipulatif. Peneliti melanjutkan pembuatan LKPD berdasarkan desain awal yang telah dibuat. LKPD yang telah dibuat akan divalidasi oleh dosen ahli. Validasi ini dilakukan untuk memperoleh penilaian mengenai tampilan, materi, media yang digunakan, dan tujuan pembuatan LKPD. Hasil penilaian akan digunakan sebagai pedoman revisi sehingga dihasilkan LKPD yang layak uji. LKPD yang telah dikembangkan dan dinyatakan layak uji oleh dosen ahli selanjutnya akan diuji cobakan kepada peserta didik di SMP Negeri 5 Mukok Kalimantan Barat. Pada peserta didik diberikan angket respon dan tes untuk mengetahui kelayakan dan efektifitas produk yang telah dikembangkan. Uji coba dilakukan dengan dua cara, yaitu uji coba kelompok kecil pada 9 peserta didik kelas VII B dan uji coba kelompok besar pada seluruh peserta didik kelas VII A yang berjumlah 20 peserta didik. Setelah LKPD diujicobakan maka peneliti melakukan evaluasi dengan cara menganalisis angket respon dan hasil tes peserta didik. Setelah dianalisis maka akan diketahui kualitas, nilai manfaat, dan respon peserta didik terhadap LKPD yang dikembangkan.

Jenis data yang diperoleh yaitu data kuantitatif dan data kualitatif. Data kuantitatif diperoleh dari skor angket penilaian validator dan penilaian peserta didik. Data kualitatif adalah data yang berupa deskripsi dalam bentuk kalimat, seperti kritik dan saran validator terhadap produk yang dikembangkan dan deskripsi keterlaksanaan uji coba produk. Teknik pengumulan data dilakukan dengan dua cara, yaitu wawancara dan angket. Instrumen ini berupa instrumen validasi ahli dan instrumen uji coba produk. Instrumen yang digunakan memiliki 4 pilihan jawaban, sehingga skor penilaian total dapat dicari dengan menggunakan rumus yang dikemukan oleh Novitasari dan Dewa(Nurwani, 2017) :

$$
\bar{x}=\frac{\sum_{i=1}^{n} x_{i}}{n}
$$

Dengan :

$$
x_{i}=\frac{\text { jumlah skor }}{\text { skor maksimal }} \times 4
$$

Masing-masing konten memiliki skor yang berbeda yang mengartikan tingkat validasi LKPD berbasis inkuiri terbimbing berbantuan media manipulatif. Kriteria kevalidan disajikan dalam Tabel 1. 
Tabel 1 Kriteria Validasi

\begin{tabular}{ccc}
\hline Skor Kualitas & Kriteria Kelayakan & Keterangan \\
\hline $3,26<\bar{x} \leq 4,00$ & Valid & Tidak revisi \\
$2,51<\bar{x} \leq 3,26$ & Cukup Valid & Revisi sebagian \\
$1,76<\bar{x} \leq 2,51$ & Kurang Valid & Revisi sebagian dan pengkajian ulang \\
$1,00<\bar{x} \leq 1,76$ & Tidak Valid & materi \\
\hline
\end{tabular}

Sumber (Nurwani, 2017)

Angket respon peserta didik terhadap penggunaan produk memiliki 4 pilihan jawaban dengan skor yang berbeda. Hasil dari skor angket tersebut kemudian dicari rata-ratanya dan dikonversikan ke pernyataan untuk menentukan kelayakan LKPD berbasis inkuiri terbimbing berbantuan media manipulatif. Berikut kriteria kelayakan analisis rata-rata angket respon peserta didik:

Tabel 2 Kriteria Kelayakan Dari Angket Respon Peserta Didik

\begin{tabular}{cc}
\hline Skor Kualitas & Kriteria \\
\hline $3,26<\bar{x} \leq 4,00$ & Sangat Layak \\
$2,51<\bar{x} \leq 3,26$ & Layak \\
$1,76<\bar{x} \leq 2,51$ & Cukup Layak \\
$1,00<\bar{x} \leq 1,76$ & Kurang Layak \\
\hline
\end{tabular}

Sumber (Nurwani, 2017) (dimodifikasi)

Setelah dilakukan analisis kelayakan maka dilakukan analisis keefektifan perangkat pembelajaran. LKPD dikatakan efektif jika lebih dari $60 \%$ peserta didik mencapai Kriteria Ketuntasan Minimum (KKM). Menghitung persentase ketuntasan dilakukan dengan cara sebagai berikut (Fannie \& Rohati, 2014):

$$
p=\frac{n_{t}}{n} \times 100 \%
$$

Dengan :

$p$ : persentase ketuntasan belajar

$n_{t} \quad$ : banyak peserta didik yang tuntas

$n$ : banyak peserta didik yang mengikuti tes

Dengan kriteria ketuntasan sebagai berikut :

Tabel 3 Kriteria Ketuntasan Hasil Belajar

\begin{tabular}{cc}
\hline Persentase Skor $(\%)$ & Kriteria \\
\hline$p>80$ & Sangat Baik \\
$60<p \leq 80$ & Baik \\
$40<p \leq 60$ & Cukup \\
$20<p \leq 40$ & Kurang \\
$p \leq 20$ & Sangat Kurang \\
\hline
\end{tabular}

Sumber (Rokhman, 2016) (dimodifikasi)

Produk yang dikembangkan dikatakan efektif, jika kriteria yang dicapai minimal baik. 


\section{HASIL DAN PEMBAHASAN}

Penelitian pengembangan ini menghasilkan suatu produk pembelajaran berupa Lembar Kerja Peserta Didik (LKPD) Berbasis Inkuiri Terbimbing Berbantuan Media Manipulatif pada materi Bangun Datar Segi Empat untuk SMP kelas VII. Analisis kurikulum yang dilakukan menunjukkan bahwa SMP Negeri 5 Mukok Kalimantan Barat menggunakan Kurikulum 2013 (K13) Revisi 2017. Bagian dari K13 yang dianalisis adalah tentang Kompetensi Inti, Kompetensi Dasar, Indikator Pembelajaran dari materi Bangun Datar Segi Empat. Analisis karakteristik peserta didik dari hasil pengamatan langsung terhadap proses pembelajaran menunjukkan bahwa peserta didik terlihat kurang aktif dalam kegiatan pembelajaran, peserta didik hanya menghafalkan rumus tanpa memahami konsep, dan sebagian peserta didik kurang memahami materi yang disampaikan oleh pendidik. Hasil pengamatan tersebut menunjukkan bahwa peserta didik SMP Negeri 5 Mukok Kalimantan Barat memenuhi syarat sebagai subjek penelitian uji coba lapangan. Selain itu, penggunaan LKPD dan media pembelajaran juga masih jarang dilakukan oleh pendidik.

Setelah melakukan analisis maka tahap selanjutnya adalah tahap perencanaan LKPD yang dapat menemukan suatu konsep dengan bimbingan dari pendidik serta bantuan dari media manipulatif. Tahap pengembangan adalah tahap pembuatan LKPD sesuai dengan langkahlangkah inkuiri terbimbing yang memiliki 6 tahapan yang harus dilakukan, yaitu orientasi, merumuskan masalah, merumuskan hipotesis, mengumpulkan data, menguji hipotesis dan merumuskan kesimpulan. Pada tahap orientasi LKPD memaparkan Kompetensi Dasar, Indikator dan Tujuan Pembelajaran. Tahap selanjutnya yaitu merumuskan masalah, dimana peserta didik diberikan permasalahan yang berkaitan dengan kehidupan sehari-hari tentang layang-layang, trapesium dan jajar genjang. Setelah itu peserta didik membuat dugaan sementara dari rumusan masalah yang ada pada permasalahan. Peserta didik diminta untuk melakukan eksperimen dalam tahap pengumpulan data guna menguji dugaan yang dibuat. Eksperimen ini dilakukan dengan cara memotong gambar yang diberikan oleh peserta didik dan menempelkannya sesuai dengan petunjuk dalam LKPD. Setelah mengumpulkan data, peserta didik menguji dugaan yang telah dibuat dan membuat kesimpulan dengan menuliskan penemuan yang diperoleh pada kotak kesimpulan sesuai persetujuan pendidik. Tahap selanjutnya peserta didik diminta untuk mengerjakan soal uji pemahaman untuk mengetahui sejauh mana pemahaman konsep peserta didik terhadap materi yang dipelajari. Setelah itu, peserta didik diminta untuk mengerjakan soal tes dan mengisi angket respon peserta didik.

Selanjutnya dibahas mengenai data yang diperoleh dalam penelitian dan pengembangan ini. Uji validasi LKPD yang dikembangkan terdiri dari tiga validasi, yaitu validasi ahli materi oleh guru mata pelajaran matematika SMP kelas VII, validasi ahli media oleh dosen pendidikan matematika Universitas Kanjuruhan Malang, dan validasi ahli pembelajaran oleh dosen pendidikan matematika Universitas Kanjuruhan Malang. Hasil validasi ahli materi yaitu 3,4, diperoleh kevalidan dengan kriteria valid. LKPD yang dikembangkan oleh peneliti adalah dapat digunakan dalam penelitian. Saran dan komentar ahli materi adalah kurang teliti dalam pengetikan. Hasil validasi ahli media yaitu 3,33, diperoleh kevalidan dengan kriteria valid. LKPD dikembangkan oleh peneliti dapat digunakan dalam penelitian. Saran dan komentar dari validator ahli media adalah soal uji pemahaman perlu disesuaikan dengan tujuan dan indikator pembelajaran. Hasil validasi ahli pembelajaran yaitu 3,54, diperoleh kevalidan dengan kriteria valid. LKPD yang dikembangkan peneliti dapat digunakan dalam penelitian.

LKPD yang telah di uji validasi oleh ahli materi, ahli media, dan ahli pembelajaran, selanjutnya diujicobakan kepada peserta didik dalam kelompok kecil dan kelompok besar untuk mengetahui kelayakan dan keefektifannya. Hasil belajar dan hasil angket respon peserta didik untuk uji coba kelompok kecil dapat dilihat pada Tabel 4. 
Tabel 4 Data Hasil Belajar dan Angket Respon Peserta Didik Uji Kelompok Kecil

\begin{tabular}{cccc}
\hline No & Nama & Nilai & Skor Rata-rata \\
\hline 1 & APF & 87 & 3 \\
\hline 2 & DM & 87 & 3,4167 \\
\hline 3 & FM & 75 & 3,5833 \\
\hline 4 & FY & 69 & 4 \\
\hline 5 & GYM & 69 & 4 \\
\hline 6 & ND & 81 & 4 \\
\hline 7 & MD & 87 & 3,5 \\
\hline 8 & MS & 94 & 3,75 \\
\hline 9 & R & 75 & 3,5833 \\
\hline \multicolumn{4}{c}{ Jumlah } \\
\hline \multicolumn{5}{c}{ Rata-rata Total } & 32,833 \\
\hline \multicolumn{4}{c}{}
\end{tabular}

Berdasarkan total skor rata-rata yaitu 3,64, diperoleh kriteria kelayakan dengan kriteria sangat layak. Keefektifan LKPD pada uji coba kelompok kecil menunjukkan bahwa 2 dari 9 peserta didik masih belum mencapai KKM. Persentase ketuntasan adalah $78 \%$ dengan kriteria baik, sehingga dapat dikatakan bahwa LKPD yang dikembangkan efektif.

Hasil belajar dan hasil angket respon peserta didik untuk uji coba kelompok besar dapat dilihat pada Tabel 5.

Tabel 5 Data Hasil Belajar dan Angket Respon Peserta Didik Uji Kelompok Besar

\begin{tabular}{|c|c|c|c|}
\hline No & Nama & Nilai & Skor Rata-rata \\
\hline 1 & A & 75 & 3,916667 \\
\hline 2 & $\mathrm{CBP}$ & 75 & 3,583333 \\
\hline 3 & DDT & 62 & 4 \\
\hline 4 & $\mathrm{E}$ & 81 & 3,916667 \\
\hline 5 & $\mathrm{FE}$ & 87 & 3,333333 \\
\hline 6 & FY & 94 & 3,25 \\
\hline 7 & FEO & 75 & 4 \\
\hline 8 & $\mathrm{~K}$ & 75 & 3,833333 \\
\hline 9 & $\mathrm{~L}$ & 81 & 3,833333 \\
\hline 10 & AA & 69 & 4 \\
\hline 11 & MS & 75 & 3,416667 \\
\hline 12 & OD & 75 & 3,666667 \\
\hline 13 & OT & 75 & 4 \\
\hline 14 & OLS & 81 & 3,75 \\
\hline 15 & PA & 87 & 3,25 \\
\hline 16 & PK & 75 & 4 \\
\hline 17 & $\mathrm{RS}$ & 87 & 3,416667 \\
\hline 18 & $\mathrm{RD}$ & 87 & 3,25 \\
\hline 19 & $\mathrm{~S}$ & 81 & 3,75 \\
\hline 20 & YL & 81 & 3,5 \\
\hline \multicolumn{3}{|c|}{ Jumlah } & 73,66667 \\
\hline \multicolumn{3}{|c|}{ Rata-rata Total } & 3,683333 \\
\hline
\end{tabular}


Berdasarkan total skor rata-rata yaitu 3,68, diperoleh kriteria kelayakan dengan kriteria sangat layak. Keefektifan dari uji coba kelompok besar menunjukkan bahwa nilai 2 dari 20 peserta didik masih belum mencapai KKM yaitu $<70$. Persentase uji coba pada kelompok besar ini adalah $90 \%$, diperoleh kriteria keefektifan adalah sangat baik. Pada uji coba kelompok besar ini diperoleh bahwa LKPD yang dikembangkan efektif.

Peneliti juga melakukan wawancara kepada guru matematika dan peserta didik di SMP Negeri 5 Mukok Kabupaten Sanggau Kalimantan Barat. Hasil wawancara dengan guru matematika, menyimpulkan bahwa LKPD sangat penting kaitannya dengan kegiatan pembelajaran, karena LKPD merupakan salah satu sarana yang digunakan dalam menyampaikan materi ajar selain buku paket. LKPD dapat memudahkan pendidik dalam penyampaian materi ajar dan membantu peserta didik memhami konsep dari suatu materi. LKPD yang dibuat juga harus sesuai dengan $\mathrm{KD}$, selain memuat materi ajar dan soal, penyusunan LKPD juga harus memperhatikan tampilan seperti warna dan gambar agar dapat menarik minat peserta didik. Hasil wawancara dengan peserta didik menyimpulkan bahwa LKPD sangat dibutuhkan dalam proses pembelajaran. LKPD yang dibuat juga harus terdapat pendukung seperti gambar dan warna yang bervariasi serta kombinasi antara gambar dan warna menarik. Pada pembuatan LKPD tidak cukup dengan materi dan soal saja, namun harus memperhatikan kemenarikan gambar, warna dan pendukung lainnya seperti media yang digunakan agar peserta didik tidak merasa bosan.

Hasil validasi ahli materi pada aspek memperoleh skor 3,4 dengan kriteria valid. Validasi ahli media memperoleh skor 3,33 dengan kriteria valid dan validasi ahli pembelajaran memperoleh skor 3,54 dengan kriteria valid, sehingga diperoleh bahwa LKPD valid untuk diterapkan pada materi bangun datar, yaitu penemuan rumus layang-layang, trapesium, dan jajar genjang. Hasil respon peserta didik terhadap LKPD yang dikembangkan menunjukkan bahwa total rata-rata angket respon peserta didik adalah 3,66 sehingga LKPD yang dikembangkan sangat layak digunakan pada materi bangun datar. Tes belajar peserta didik menunjukkan keefektifan LKPD yang dikembangkan diperoleh 4 dari 29 subyek penelitian belum mencapai KKM, yaitu mendapat nilai $<70$. Dari total rata-rata uji kolompok kecil dan kelompok besar diperoleh persentase ketuntasan sebesar $84 \%$ dan ini mencapai kategori sangat baik karena melebihi persentase $80 \%$, sehingga LKPD ini dikatakan sangat efektif diterapkan pada materi bangun datar, yaitu penemuan rumus layang-layang, trapesium, dan jajar genjang.

\section{PENUTUP}

Kesimpulan yang diperoleh dari penelitian dan pengembangan ini adalah Lembar Kerja Peserta Didik (LKPD) berbasis inkuiri terbimbing berbantuan media manipulatif pada materi bangun datar dalam pembelajaran matematika di kelas VII SMP Negeri 5 Mukok Kalimantan Barat yang dihasilkan telah dinyatakan layak dan efektif untuk digunakan sebagai bahan ajar. Selain itu, hasil wawancara menunjukkan bahwa LKPD yang dikembangkan menarik berdasarkan respon peserta didik. Saran untuk peneliti selanjutnya agar dapat mengimplementasikan LKPD dengan bantuan berbagai media pada materi lain dalam pembelajaran matematika.

\section{DAFTAR PUSTAKA}

Damayanti, D. S. (2013). Pengembangan Lembar Kerja Siswa ( LKS ) Dengan Pendekatan Inkuiri Terbimbing Untuk Mengoptimalkan Kemampuan Berpikir Kritis Peserta Didik Pada Materi Listrik Dinamis SMA Negeri 3 Purworejo Kelas X Tahun Pelajaran 2012 / 2013. RADIASI, 3(1), 58-62.

Fannie, R. D., \& Rohati. (2014). Pengembangan Lembar Kerja Siswa (LKS) Berbasis POE (Predict, Observe, Explain) Pada Materi Program Linear Kelas XII SMA. Jurnal Sainmatika, 8(1), 96-109.

Indraningtias, D. A., \& Wijaya, A. (2017). Pengembangan Perangkat Pembelajaran Berbasis Pendekatan Matematika Realistik Materi Bangun Ruang Sisi Datar Berorientasi Pada 
Kemampuan Berpikir Kritis Siswa Kelas VIII SMP. Jurnal Pendidikan Matematika-S1, 6(5), 24-36.

Indriani, M. (2017). Pengembangan Lembar Kerja Peserta Didik (LKPD) Berbasis Inkuiri Terbimbing Pada Materi Transformasi Geometri. Jurnal Pendidikan Matematika RAFA, $3(2), 165-180$.

Iskandar, D. (2018). Pembelajaran Memproduksi Teks Eksposisi Dengan Menggunakan Metode Problem Based Learning. Semantik, 7(1), 90-98.

Ningsih, S. (2014). Realistic Mathematic Education: Model Alternatif Pembelajaran Matematika Sekolah. Jurnal Pendidikan Matematika UIN Antasari, 01(2), 73-94.

Nurwani. (2017). Pengembangan Desain Dikdaktis Bahan Ajar Materi Pemfaktoran Bentuk Aljabar pada Pembelajaran Matematika SMP. Jurnal Matematika Dan Pendidikan Matematika, 1(2), 193-206.

Purwasih, R. (2015). Peningkatan Kemampuan Pemahaman Matematis Dan Self Confidence Siswa MTs Di Kota Cimahi Melalui Model Pembelajaran Inkuiri Terbimbing. Jurnal Ilmiah STKIP Siliwangi Bandung, 9(1), 16-25.

Riana, R. (2013). Penggunaan Media Manipulatif Untuk Meningkatkan Hasil Belajar SIswa Pada Pembelajaran Matematika Sekolah Dasar. Jurnal Pendidikan Dan Pembelajaran, 2(11), 1-11.

Rokhman, K. N. (2016). Pengembangan Perangkat Pembelajaran Segitiga Dan Segi Empat Dengan Pendekatan Open-Ended Untuk Meningkatkan Kemampuan Komunikasi Matematis Siswa SMP Kelas VII. Jurnal Pendidikan Matematika-S1, 5(7). 